$\mathrm{n}=86$

\section{Index Test}

CDC DENV-1-4 Real Time RT-PCR Assay

(Multiplex)

$$
\mathrm{n}=86
$$

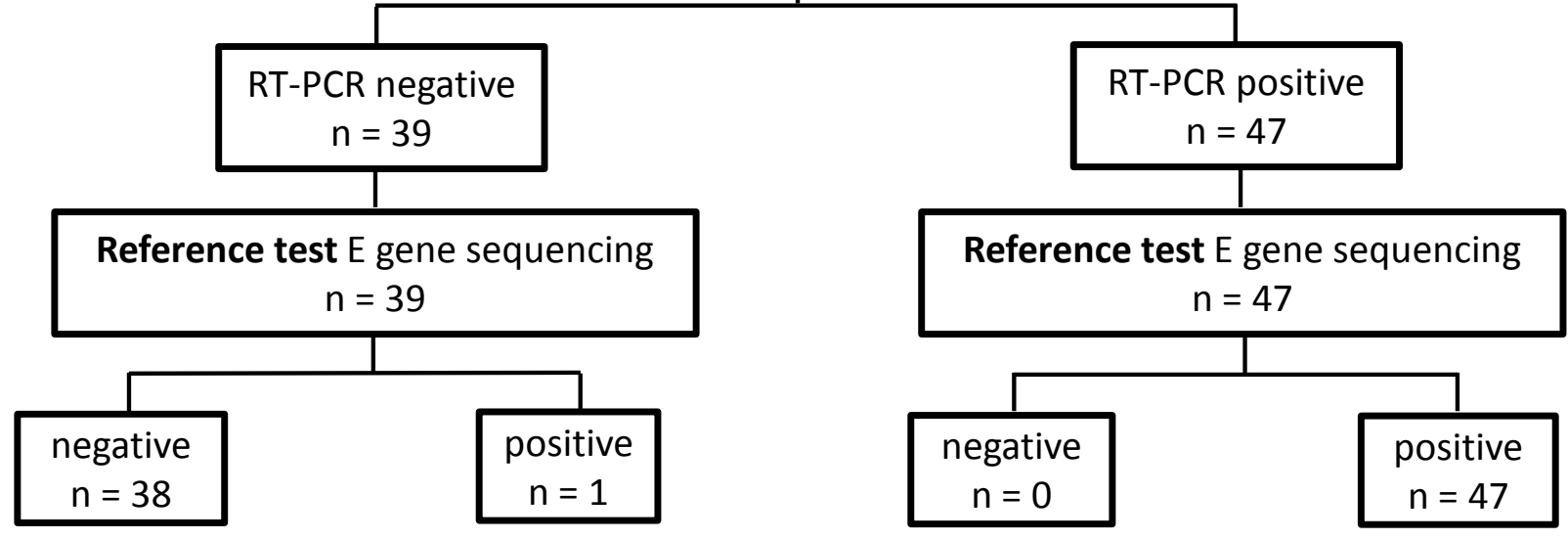

